\title{
ASSESSMENT OF THE MARINE ENVIRONMENT QUALITY BY THE METHODS OF BIOINDICATION AND BIOTESTING ON THE EXAMPLE OF THE ODESA REGION
}

\author{
Pentilyuk R.S. - Ph.D. in Agricultural Sciences, Associate Professor \\ Soborova O.M. - Ph.D. in Geography, Assistant \\ Kudelina O.Y. - Senior Lecturer \\ Odessa State Environmental University, olkasobr@gmail.com
}

The results of the researches of the marine environment quality assessment by the methods of biotesting and bioindication using hydrobionts of the different systematic levels are presented. A preliminary analysis of the reservoir trophism and the quality of the coastal waters was conducted on the basis of the quantitative indicators of toxic and potentially toxic species of microalgae in the Odessa region. The general analysis of the research results of the biodiversity and a biomass of phyto- and zooplankton, and zoobenthos of the Odesa part of the Black Sea is determined.

A quality of the coastal marine environment of the most of the surveyed water areas of the Odessa region has improved over the course of the year but it was somewhat worse for the development of the investigated hydrobionts than in 2015 . The water environment of the open areas of the NWBS in general had the significantly better environmental properties for the development of the biological objects. The underlying environment of some of these marine areas was significantly more eutrophied (in terms of a vegetation status of the benthic microphytes) than at the coast of the Odessa region. Surface water masses from the mainland slope of the NWBS in summer were characterized by the significantly better environmental properties for the morphogenesis of the test objects (mussels larvae of the early stages of their development) than all the waters from the coastal and open water areas of this part of the sea explored for the last 9 years.

The methods of biotesting of a quality of the marine environment of the coastal areas of the NWBS using physiological and morphological indicators of the state of the adult Black Sea mussels and their larvae have revealed that a quality of the aquatic environment for the life of these hydrobionts had improved (as compared to a previous year) in the most studied water areas.

In the coastal areas of the sea after the periodic changes in macrophytobenthos mesosappropriate algal species prevail and there is some stabilization of bottom phytocoenoses. Compared to previous years a species composition of macrophytobenthos changed significantly in the region of the NWBS. Some brown algae disappeared as the most sensitive to the anthropogenic pressure. But there is a massive development of filamentous green and red algae because of the excess of the pollutants. Thus the adaptation of macrophytes to the changing environmental conditions occurs and it is expressed in a change of a structural organization and in a slight tendency to their restoration at the NWBS.

Key words: The Black Sea, The Odessa Bay, phytoplankton, zooplankton, bioindication, biotesting. 
Formulation of the problem. Biodiversity is one of the most advanced methods of assessing the state of the marine biota. Its maximum level is usually observed in the coastal areas at the shallow depths. The biodiversity of the ecosystem also reflects its ecological state [4].

Analysis of the research and publications. Microfitobenthos plays an important role in the structure of aquatic biocenoses. It takes an active part in the cycle of substances and the energy of reservoirs, acting as a primary link of a food chain. The mixotrophic method of feeding many types of algae promotes to the biological purification of the reservoirs. At the same time an excessive development of algae with their subsequent extinction can cause a secondary contamination of the coastal water areas. In the coastal areas of the sea after the periodic changes in macrophytobenthos, mesosappropriate algal species predominate and, as a rule, there is a certain stabilization of bottom phytocoenoses. In the port area of the city of Yuzhny in the Odesa region, which occupies a water part of the Grigoryevsky estuary, especially in the vicinity of the waste water discharges in the Gulf of Odessa, the species diversity of macrophytes is 2-2,5 times less than in the whole Odessa region. In the coastal areas mesosaprobic species of algae are dominated. A quality of the shallow water of the North Western Part of the Black Sea (NWBS) at the present stage refers to moderately polluted. With regard to the open shelf zone, here a share of oligosaprobic species is about $70 \%$ which despite the elevated level of eutrophication characterizes this area as relatively clean.

Phytoplankton, as a component of the aquatic ecosystem, is extremely responsive to any changes in the environment and is an effective indicator of an ecological state of the aquatic environment.

Zooplankton is conventionally divided into holoplankton (a real plankton), whose ontogenesis takes place exclusively in the thickness of the water masses, and meroplankton (a temporary component of zooplankton), represented predominantly by larvae of the benthic animals. A number of zooplankton species is significantly increased during the development of meroplankton due to the period of a benthic fauna reproduction.

Historical development of the Black Sea water area and low salinity of its waters cause a sufficient variety of flora and fauna. According to the origin the biota includes: 1) the ancient relict brackish fauna, which is a remnant of the Pontic fauna; 2) the Mediterranean (in other words, the Atlantic) fauna and flora - it is like the youngest invader and now its most complete owner; 3) freshwater forms. The habitat of the zoobenthos of the Black Sea is $23 \%$ of the Black Sea area. The lower limit of a macrozoobenthic animal's distribution is located at the depths of $130 \mathrm{~m}$.

A biomass of benthos in the Black Sea is quite high. It is about $100 \mathrm{~g} / \mathrm{m}^{2}$ in the coastal areas of the Western Crimea, and $100-500 \mathrm{~g} / \mathrm{m}^{2}$ in the southern shores of the Crimea. The most productive area is the NWBS. 
In the Odesa-Danube part of the NWBS at the depths of 10-30 m and 60-80 m benthos develops weakly, which is associated with the long sprat catch and obscure phenomena. In the shelf part of the NWBS at the depths of $30-50 \mathrm{~m}$ the maximum of benthos biomass is observed at the places of mollusks cyanosis formation from $200 \mathrm{~g} / \mathrm{m}^{2}$ to several kilograms per $1 \mathrm{~m}^{2}$ (this is where the greatest development of mussels is noted). Starting at the depth of $50-80 \mathrm{~m}$ a benthos biomass decreases to $20-50 \mathrm{~g} / \mathrm{m}^{2}$ and from the depth of $80 \mathrm{~m}$ it is several grams per $1 \mathrm{~m}^{2}$.

Spatial distribution of macrozoobenthos is very heterogeneous and depends first of all on the nature of the soil and depths. On solid substrates in the coastal waters of the Odessa region of the NWBS the fouling groupings, where bivalve molluses are dominated (Mytilus galloprovincialis and Mytilaster lineatus), form. Also multifaceted worms (Harmothoe imbricata, Harmothoe reticulata) and crustaceans (Amphibalanus improvisus, Dexamine spinosa, Microdeutopus gryllotalpa) are the permanent components of macrozoobenthos in the coastal waters of the NWBS.

Structural-functional changes of the macrozoobenthos communities in the conditions of a long-term research serve as a reliable indicator of the state of the marine ecosystem. Over the past 10 years a species composition of the macrozoobenthos representatives has increased. According to the long-term observations in the coastal region of the Odessa region 130 macrozoobenthos taxons were recorded [4].

Research results. In 2016 when assessing the marine environment quality with the help of the biotesting and bioindication methods using the hydrobionts of the different systematic levels (mussels at the different stages of development and microfitobenthos algae) it was shown that the ecological properties of the environment of the open and coastal areas of the NWBS, different from the influence of the anthropogenic and natural factors on them, differed considerably (Fig. 1) [5].

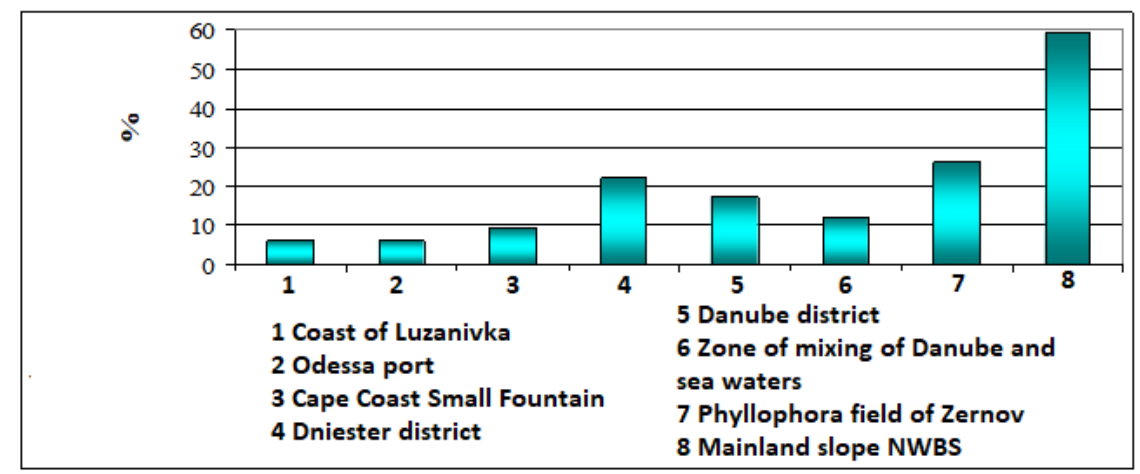

Fig. 1. Development of prodisokonh mussels of a normal morphology during the biotesting of the marine waters of NWBS in the summer season of 2016 (\%) 
A quality of the coastal marine environment of the most of the surveyed water areas of the Odessa region has improved over the course of the year but it was somewhat worse for the development of the investigated hydrobionts than in 2015. The water environment of the open areas of the NWBS in general had the significantly better environmental properties for the development of the biological objects. The underlying environment of some of these marine areas was significantly more eutrophied (in terms of a vegetation status of the benthic microphytes) than at the coast of the Odessa region. Surface water masses from the mainland slope of the NWBS in summer were characterized by the significantly better environmental properties for the morphogenesis of the test objects (mussels larvae of the early stages of their development) than all the waters from the coastal and open water areas of this part of the sea explored for the last 9 years.

In the spring-summer period 2016 at the NWBS 224 species of phytoplankton which belonged to 8 departments were observed (Fig. 2) [5].

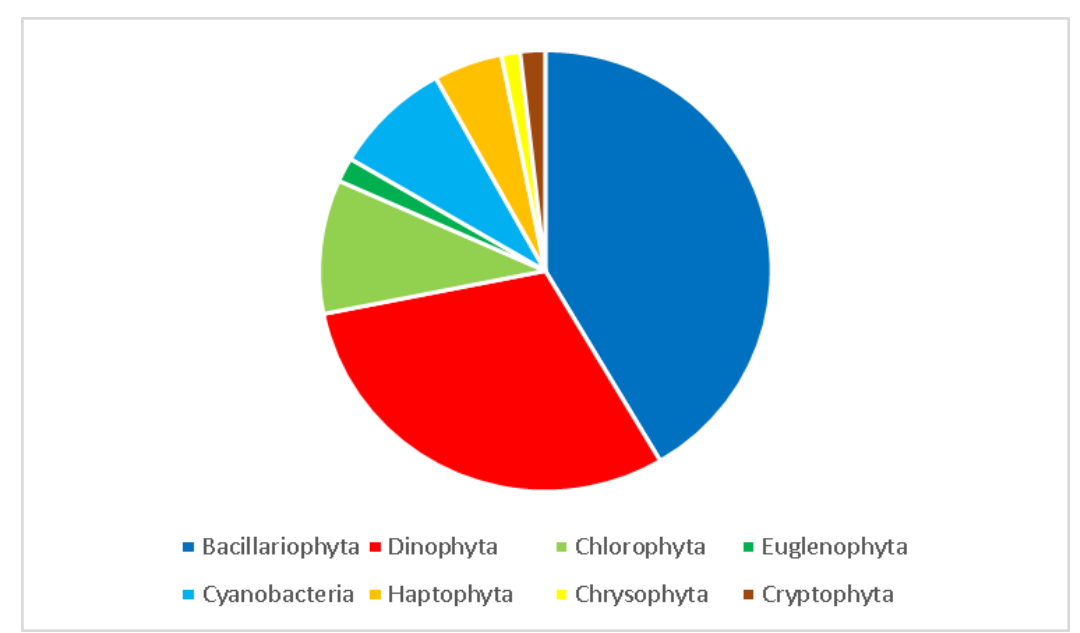

Fig. 2. Phytoplankton species diversity in the waters of the NWBS (may, 2016)

The most significant contribution to the species diversity was made by the representatives of diatoms (93 species) and dinophytes (68 species), the proportion of green algae (22 species), cyanobacteria (19 species) and haptophytovyh (11 species) was a bit less. Euglen (4 species), golden (3 species) and cryptophyte algae (4 species) were insignificant.

In the water area of the Odessa region there was a polydominant complex of phytoplankton species (212 microalgae species and varieties) with a predominance of diatom in both numbers and a biomass (Fig. 3) [5].

In the coastal areas the quantitative indicators of phytoplankton are higher than in the open shelf waters. High values of the quantitative 
indicators of phytoplankton in the coastal waters were caused by a flow of several large rivers especially the Danube River.

In the Dniester region, the average number of phytoplankton was 1003 thousand units $/ 1^{-1}$, an average biomass $-580 \mathrm{mg} \mathrm{m}^{-3}$. The high values of the quantitative indicators in this area were due to the diatoms (P. Delicatissima) "bloom". The maximum "bloom" was observed in the upper layer of the water which was located on the crossroads of the Dniester estuary, which was probably caused by a pollutants inflow within the river runoff. As the river waters flow along the coast and mix with the seawater, the "blooming" moved to the deeper horizons in the direction of a distance from the coastline and was observed only on the lower boundary of the thermocline where a number of diatom P. Delicatissima mounted to 1.98 million units $/ 1^{-1}$ at the biomass of $0.78 \mathrm{gm}^{-3}$.

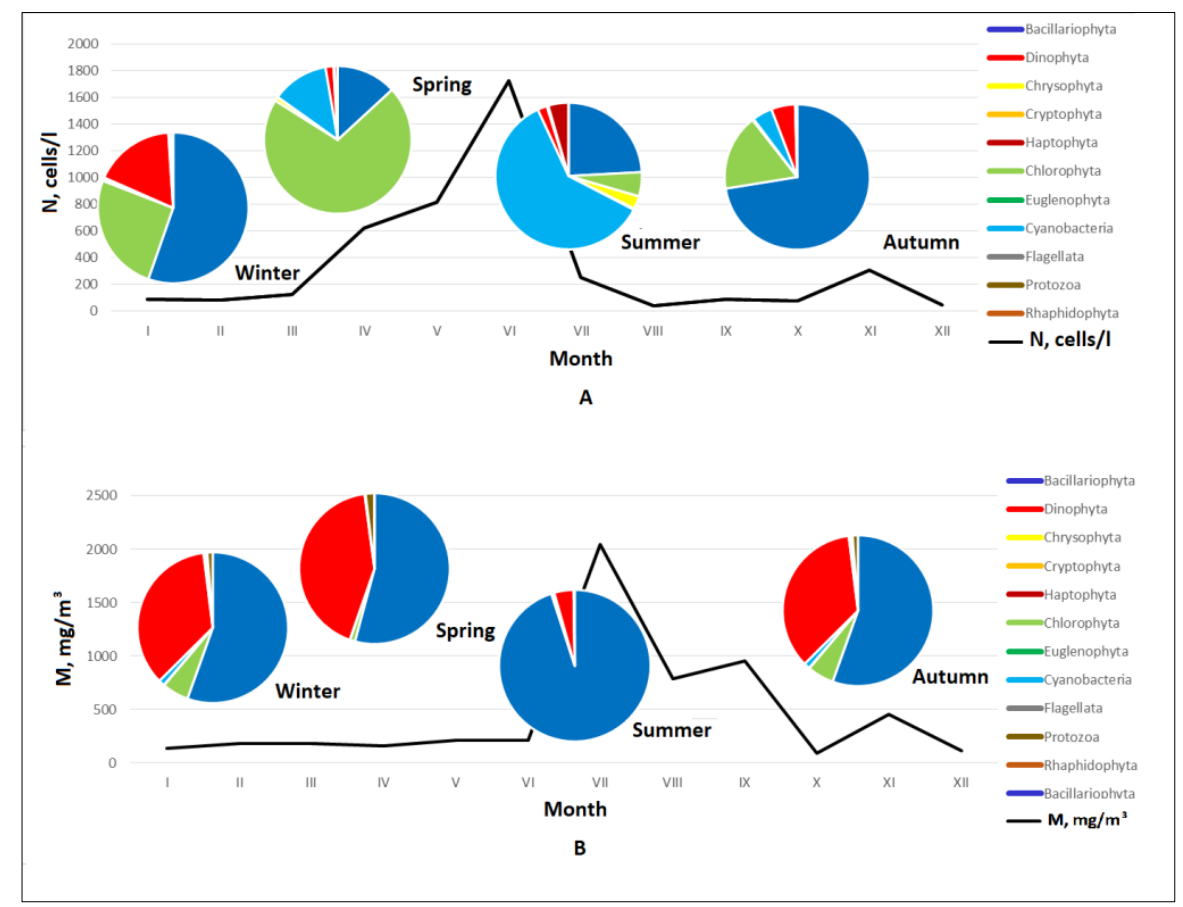

Fig. 3. Quantitative changes of phytoplankton in the Odessa region in 2016 (a-number, thousand units $\times \mathrm{I}^{-1} ; \mathrm{b}-$ biomass, $\mathrm{mg} \times \mathrm{m}^{-3}$ )

$P$. delicatissima refers to the potentially toxic species, but in spite of the occasional «blooming» of this species, any humans or animals diseases that were associated with it were not observed in the study area.

In the zone of mixed waters, the average indicators of a number of phytoplankton amounted to 525 thousand units / cubic meters, an average biomass $397 \mathrm{mg} \mathrm{m}^{-3}$. In the open waters of the shelf which are the most 
distant from the coast, a number of phytoplankton did not exceed 150 ths units $/ \mathrm{l}^{-1}$, and biomass $180 \mathrm{mg} \mathrm{m}^{3}$.

The quantitative indicators of phytoplankton decrease with increasing the distance from the coast and increase in the zones of the river runoff influence. This effect was the most pronounced in the upper mixed horizons and on the upper boundary of the thermocline and became smoother with increasing the depth. In the Danube area there was a difference in the quantitative indicators of phytoplankton in more than 100 times compared with the other areas of the NWBS.

28 taxons which are the representatives of freshwater saltwater and marine complexes were registed in the zooplankton composition of the Odessa region. An average biomass was $39.56 \mathrm{mg} \mathrm{m}^{-3} \pm 21.02 \mathrm{mg} \mathrm{m}^{-3}$. The changes in a zooplankton biomass during the year are shown in Figure 4 [5].

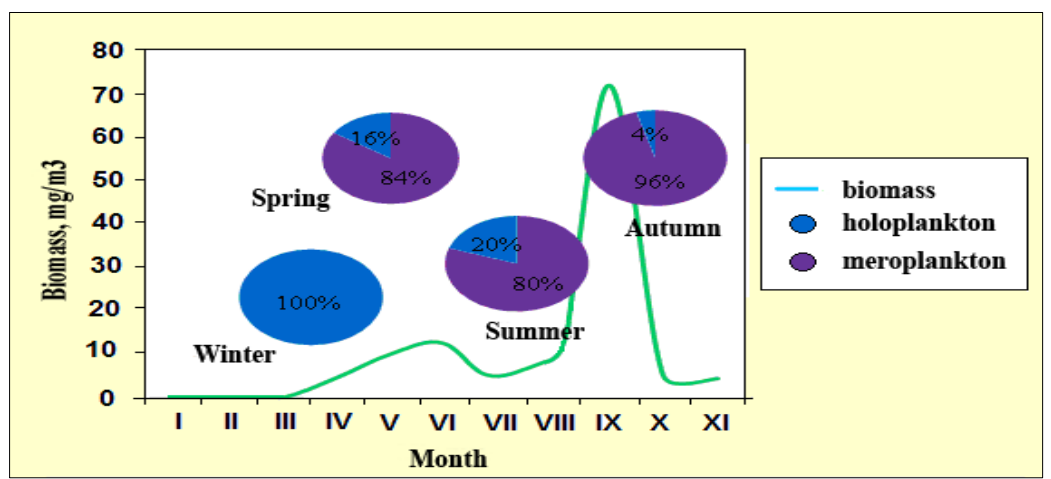

Fig. 4. An average biomass $\left(\mathrm{mg} \mathrm{m}^{-3}\right)$ of zooplankton in the Odessa region in 2016

On average in the Odessa region in a seasonal zooplankton biomass two peaks - in summer and autumn - were noted: the first maximum of the biomass was at the end of June, the second was in September, and they were due to the development of the nauplial stages of crustaceans Balanus (Cirripedia).

There is a constant tendency to improve a state of the zooplankton group, as evidenced by the changes in the structure of zooplankton: a decrease of non-trophic zooplankton ( $N$. scintillans), and a simultaneous increase in the number and biomass of a trophic component.

In the Danube Region 21 taxons of zooplankton were registered in autumn, among which there were 12 taxons of crustaceans, and a good state of a forage base for planktophagous fish was observed. An average number and a biomass of zooplankton was 6827.96 units $/ \mathrm{m}^{-3} \pm 6645.15$ units $/ \mathrm{m}^{-3}$ and 57.09 units $/ \mathrm{m}^{-3} \pm 34.07$ units $/ \mathrm{m}^{-3}$ respectively. Copepoda-invader Oithonabrevicornis played a significant role in the formation of the quantitative indicators of a zooplankton development. A state of a zooplankton group of the Danube Region has a tendency to improve their 
condition, which is expressed in increasing the diversity, especially crustaceans, in a complexity of the structure and in a reduction of a nonfodder part for fish.

In 2016105 taxons of macrozoobenthos were detected in the studied areas of the Black Sea shelf in Ukraine. The largest variety was shown by the following groups - Annelida, Crustacea and Mollusca. A number of species varied from 9 to 44 by sample. The Whitteker Beta Spread Diversity Index was 3.28.

Biocenoz of Chameleagallina on the sandy soil at the depths from 16 till $24 \mathrm{~m}$ (the Dniester district): A total number of animal species in the community was 35, among them: Polychaeta - 14, Phoronida - 1, Gastropoda - 1, Bivalvia - 6, Cirripedia-1, Amphipoda-3, Cumacea - 2, Mysida - 2, Tanaidacea - 1 and Decapoda - 1. An average number and a biomass reached 2,522 by sample $/ \mathrm{m}^{2}$ and $353 \mathrm{~g} / \mathrm{m}^{2}$ respectively. About $80 \%$ of the biomass was given by the bivalves - Chameleagallina, Spisulasubtruncata and Anadarakagoshimensis. Polychaetes accounted for about $74 \%$ of the population.

Infolithic dirty sand with the thalassinozide overgrown at the depths up to $20 \mathrm{~m}$ (the Danube region): In this biocenose 31 taxons belonging to 10 systematic groups (Anthozoa - 1, Polychaeta - 16, Gastropoda - 1, Bivalvia-2, Cirripedia - 1, Amphipoda - 2, Cumacea - 1, Decapoda - 5) were identified. An average number and a biomass was 2946 by sample/m² and $45 \mathrm{~g} / \mathrm{m}^{2}$ respectively.

Biocenose of Mytilusgallo provincialis, the biogenic reefs, at the depths from 13 till $19 \mathrm{~m}$ : In the macrozoobenthos there are 60 taxons, most of them $(40 \%)$ belong to Polyhete (Anthozoa - 1, Polychaeta - 24, Gastropoda - 4, Bivalvia - 11, Cirripedia - 1, Amphipoda - 7, Cumacea 2, Isopoda - 1 and Decapoda-6). Polychetes and bivalve molluscs reached the highest volume in the samples. An average content of macrozoobenthous populations was 11,364 by sample $/ \mathrm{m}^{2}$ and $271 \mathrm{~g} / \mathrm{m}^{2}$ of the number and a biomass respectively.

Terrigenous silt, biocenose of Melinnapalmata at the depths from 19 till 24 m: There were 26 species: Cnidaria - 3, Phoronida - 1, Polychaeta 4, Gastropoda-3, Bivalvia-9, Amphipoda-1, Decapoda-3. In places the biomass of Mya arenaria was up to $300 \mathrm{~g} / \mathrm{m}^{2}$.

Organogenic sand with Mytilus biogenic reefs and filamentous / leafy algae at the depths from 31till $52 \mathrm{~m}$ (a district of FPP): 34 taxons belonging to 11 systematic groups were identified: Polychaeta - 13, Bivalvia - 2, Amphipoda - 9, Isopoda-1, Cumacea - 1, Mysida-1, Tanaidacea - 1, Echinodermata - 1, Tunicata - 2. An average number and a biomass amounted to 911 by sample $/ \mathrm{m}^{2}$ and $231.6 \mathrm{~g} / \mathrm{m}^{2}$. Polycetts were $59 \%$ of the total number where Prionospiomultibranchiata was $30 \%$. Mytilusgalloprovincialis was a sub-dominant in a number and a dominant in a biomass, as a characteristic habitat. Within the macrozoobenthos of the Odessa region (up to $3 \mathrm{~m}$ depth) 30 taxons were registered: Vermes - 9, Mollusca-7, Crustacea-11, Varia-3. An average population was 6,244 
by sample $/ \mathrm{m}^{2}$, and a biomass was $145,12 \mathrm{~g} / \mathrm{m}^{2}$. The appearance of some types of crustaceans in the macrozoobenthos indicates an increase in a fish feed base.

According to the obtained results, it can be noted that in general a macrozoobenthos state is satisfactory and tends to improve the condition both in terms of variety and in the quantitative parameters.

13 taxonomic groups (depths $19-50 \mathrm{~m}$ ) were discovered in the meiobenthos of the NWBS. Foraminifera (Foraminifera) and nematodes (Nematoda) (69\% of multicellular meiobenthos) dominated by a number. Crustacea (Harpacticoida and Ostracoda) represented by a maximum at the depths of 19-28 m (28\%) was a sub-dominant group. The maximum biomass was marked up to a depth of $20 \mathrm{~m}$ and was formed predominantly by the weight of pseudomembeenthost ranging from $79 \%$ to $99 \%$. The total number of meiobenthos on the mallow soil is almost twice as high as in the shellfish and turmeric shells and three times higher than on the sandy soils. Most of the NWBS areas are characterized by a good environmental state of the benthos according to a structure of the meiobenthic organisms $-57 \%$ of the stations are characterized by a good ecological state and $43 \%$ of the stations are not meeting a good ecological state according to the WFD criteria.

According to long-term observations of the past years in the winter diatoms and green algae (59\% and 16\%, respectively) dominated in the species of phytoplankton, dinophytes (11\%) also made a significant contribution to a species diversity, $7 \%$ belonged to the representatives of haptophytovyh and cyanobacteria. As a result of severe desalination such freshwater blue-green algae as afaniosomenone and anaben, sea dinophytes (ekziviella, prorocentrum, glenodynium) and diatoms (skeletonema, oscinoidiscus, rhizosolenia and hetoserase) are massively developing. During spring blooming an average diatom biomass was $7 \mathrm{~g} / \mathrm{m}^{3}$, in some areas the biomass indicators were 100 and even $200 \mathrm{~g} / \mathrm{m}^{3}$, almost entirely due to blue-green algae; during the autumn maximum a biomass of dinophytes reaches up to $2 \mathrm{~g} / \mathrm{m}^{3}$.

A biomass of zooplankton in the long-term observations of the past years in the winter period was up to $150 \mathrm{mg} / \mathrm{m}^{-3}$, and a large number of jellyfish was noted $[4,5]$.

Conclusions. The methods of biotesting of a quality of the marine environment of the coastal areas of the NWBS using physiological and morphological indicators of the state of the adult Black Sea mussels and their larvae have revealed that a quality of the aquatic environment for the life of these hydrobionts had improved (as compared to a previous year) in the most studied water areas.

In 2016 in the spring-summer period in the NWBS area there was a development of 224 species of phytoplankton, which belonged to 8 departments. The representatives of diatomaceous and dinophytic microalgae made the most significant contribution to a species diversity. In the waters of the Odessa region there was a polydominant complex of phytoplankton (212 species and varities of microalgae) with a predominance of diatomaceous species both in numbers and 
in a biomass. In the coastal areas the quantitative indicators of phytoplankton are higher than in the open shelf waters. High values of the quantitative indicators of phytoplankton in the coastal waters were caused by a flow of several large rivers especially the Danube River.

In 2016105 macrozoobenthos taxons were detected in the studied zones of the Black Sea shelf of Ukraine. The largest variety was shown by the following groups - Annelida, Crustacea and Mollusca. A number of species varied from 9 to 44 by sampling. The Whitteker Beta Spread Diversity Index was 3.28. 30 taxons were registered within the macrozoobenthos of the Odessa region (up to 3 meters deep). An average number was 6,244 units $/ \mathrm{m}^{2}$, and a biomass was $145,12 \mathrm{~g} / \mathrm{m}^{2}$. The appearance of some types of crustaceans in the macrozoobenthos indicates an increase in a fish feed base. According to the obtained results it can be noted that in general the macrozoobenthos state is satisfactory and tends to improve both by variety and by the quantitative parameters.

In the coastal areas of the sea after the periodic changes in macrophytobenthos mesosappropriate algal species prevail and there is some stabilization of bottom phytocoenoses. Compared to previous years a species composition of macrophytobenthos changed significantly in the region of the NWBS. Some brown algae disappeared as the most sensitive to the anthropogenic pressure. But there is a massive development of filamentous green and red algae because of the excess of the pollutants. Thus the adaptation of macrophytes to the changing environmental conditions occurs and it is expressed in a change of a structural organization and in a slight tendency to their restoration at the NWBS.

\title{
ОЦЕНКА КАЧЕСТВА МОРСКОЙ СРЕДЫ МЕТОДАМИ БИОИНДИКАЦИИ И БИОТЕСТИРОВАНИЯ НА ПРИМЕРЕ ОДЕССКОГО РЕГИОНА
}

\author{
Пентилюк Р.С. - к. с.-х. н., доцент \\ Соборова О.М. - к. геогр. н., ассистент \\ Куделина О.Ю. - старший преподаватель \\ Одесский государственный экологический университет, olkasobr@gmail.com
}

Представлены результаты исследований оценки качества морской среды по методам биотестирования и биоиндикации с использованием гидробионтов различных систематических уровней. Проведен предварительный анализ трофности водоема и качества прибрежных вод на основе количественных показателей токсичных и потенциально токсичных видов микроводорослей в Одесском регионе. Определен общий анализ результатов исследований по биоразнообразию и биомассой фито- и зоопланктона, и зообентоса Одесской части Черного моря.

Качество прибрежной морской окружающей среды большинства обследованных акваторий Одесского региона в течение года улучшилось, но было несколько хуже для развития исследованных гидробионтов, чем в 2015. Водная среда открытых районов СЗЧМ в целом имела значительно лучшие экологические свойства для развития биологических объектов. Придонная 
среда некоторых из этих морских участков была более значительно евтрофицирована (по показателям состояния вегетации бентосных микрофитив), чем в прибрежье Одесского региона. Поверхностным водным массам из района материкового склона СЗЧМ летом были присущи значительно лучше экологические свойства для морфогенеза тест-объектов (личинок мидий ранних стадий развития), чем всем исследованным за последние 9 лет водам с прибрежных и открытых акваторий этой части моря.

Методами биотестирования качества морской среды прибрежных районов СЗЧМ с использованием физиолого-морфологических показателей состояния взрослых черноморских мидий и их личинок обнаружено, что качество водной среды для жизнедеятельности этих гидробионтов улучшилось (по сравнению с предыдущим годом) на большинстве исследованных акваторий).

В прибрежных районах моря после периодических изменений макрофитобентоса, преобладают мезосапробные виды водорослей и наблюдается некоторая стабилизация донных фитоценозов. В районе ФПО по сравнению с предыдущими годами видовой состав макрофитобентоса претерпел значительные изменения. Исчезли некоторые бурые водоросли, как наиболее чувствительные к антропогенному давлению. Но наблюдается массовое развитие нитчатых зеленых и красных водорослей, этому, очевидно, способствует избыток БР. Таким образом, происходит приспособление макрофитов к меняющимся условиям внешней среды, выражающееся в изменении структурной организации и незначительной тенденцией к восстановлению на СЗЧМ.

Ключевые слова: Черное море, Одесский залив, фитопланктон, зоопланктон, биоиндикация, биотестирования.

\title{
ОЦІНКА ЯКОСТІ МОРСЬКОГО СЕРЕДОВИЩА МЕТОДАМИ БІОІНДИКАЦІЇ ТА БІОТЕСТУВАННЯ НА ПРИКЛАДІ ОДЕСЬКОГО РЕГІОНУ
}

\author{
Пентилюк Р.С. - к. с.-г. н., доцент \\ Соборова О. М. - к. геогр. н., асистент \\ Куделіна О.Ю. - старший викладач \\ Одеський державний екологічний університет, olkasobr@gmail.com
}

Представлено результати досліджень оцінки якості морського середовища за методами біотестування та біоіндикації з використанням гідробіонтів різних систематичних рівнів. Проведений попередній аналіз трофності водойми та якості прибережних вод на основі кількісних показників токсичних та потенційно токсичних видів мікроводоростей в Одеському регіоні. Визначено загальний аналіз результатів досліджень за біорізноманіттям та біомасою фіто- та зоопланктону, і зообентосу Одеської частини Чорного моря

Якість прибережного морського довкілля більшості обстежених акваторій Одеського регіону протягом року покращилась, але була дещо гіршою для розвитку досліджених гідробіонтів, ніж у 2015 р. Водне середовище відкритих районів ПЗЧМ в цілому мало значно кращі екологічні властивості для розвитку біологічних об’єктів. Придонне середовище деяких з цих морських ділянок було значно евтрофікованішим (за показниками стану вегетації бентосних мікрофітів), ніж у прибережжі Одеського регіону. Поверхневим водним масам 3 району материкового схилу ПЗЧМ влітку були притаманні значно кращі екологічні властивості для морфогенезу тест-об’єктів (личинок мідій ранніх стадій розвитку), 
ніж усім дослідженим за останні 9 років водам 3 прибережних та відкритих акваторій цієї частини моря.

Методами біотестування якості морського довкілля прибережних районів ПЗЧМ з використанням фізіолого-морфологічних показників стану дорослих чорноморських мідій та їхніх личинок виявлено, що якість водного середовища для життедіяльності цих гідробіонтів покращилася (порівняно 3 попереднім роком) на більшості досліджених акваторій).

У прибережних районах моря після періодичних змін макрофітобентосу, переважають мезосапробні види водоростей та спостерігається деяка стабілізація донних фітоценозів. В районі ФПЗ у порівнянні з попередніми роками видовий склад макрофітобентосу зазнав значних змін. Зникли деякі бурі водорості, як найбільш чутливі до антропогенного тиску. Але спостерігається масовий розвиток нитчастих зелених і червоних водоростей, цьому, очевидно, сприяє надлишок БР. Отже, відбувається пристосування макрофітів до мінливих умов зовнішнього середовища, що виражається у зміні структурної організації та незначною тенденцією до їх відновлення на ПЗЧМ.

Ключові слова: Чорне море, Одеська затока,фітопланктон, зоопланктон, біоіндикація, біотестування.

\section{ЛІТЕРАТУРА}

1. Гончаров А.Ю. Гідрохімічний режим і первинна продукція фітопланктону в районі аварійного випуску стічних вод в Одеській затоці. Екологія моря. 2001. С. 60-70.

2. Єременко T.I. Макрофітобентос. Керівництво по методах біологічного аналізу морської води і донних відкладень (тимчасове). Л.: Гідрометео вид-во, 1980. С. 170-177.

3. Ковалішина С.П., Теренько Г.В., Грандова М.А., Дудник Д.С. Стан планктонних i бентосних спільнот гідробіонтів Одеського прибережжя Чорного моря. Матеріали XI Міжнародної науковопрактичної екологічної конференції «Видові популяції і спільноти в природних i антропогенно-трансформованих ландшафтах: стан і методи його діагностики». Росія, Белгород, 20-25 вересня 2010. $107 \mathrm{c}$.

4. Матеріали до Національної доповіді про стан навколишнього природного середовища в Україні у 2015 р. Рукопис УкрНЦЕМ. Одеса, 2016. 26 с.

5. Матеріали до Національної доповіді про стан навколишнього природного середовища в Україні у 2016 р. Рукопис УкрНЦЕМ. Одеса. 2017 р. 24 с.

6. Орлова І.Г., Павленко Н.Е., Попов Ю.И., Український В.В., Коморін В.Н. Результати досліджень гідролого-гідрохімічного режиму Одеського порту в рамках міжнародного проекту «Глобалласт»: тези доп. 4-й міжнародний симпозіум. Екологічні проблеми Чорного моря. Одеса, ОЦНТІ, 31 жовтня-02 листопада 2002. C. 156-161. 
7. Зайцев Ю.П., Александрова Б.Г., Миничевой Г.Г. Північно-західна частина Чорного моря: біологія, екологія. Київ: Наукова думка, 2006. $701 \mathrm{c}$.

\section{REFERENSES}

1. Honcharov A.Yu. (2001). Hidroximichnyj rezhym i pervynna produkciya fitoplanktonu $\mathrm{v}$ rajoni avarijnoho vypusku stichnyx vod $\mathrm{v}$ Ode'kij zatoci. Ekolohiya morya. P. 60-70. [in Ukrainian]

2. Yeremenko T.I. (1980). Makrofitobentos (Macrophytobenthos). Kerivnyctvo po metodax biolohichnoho analizu mors'koyi vody i donnyx vidkladen" (tymchasove). Leningrad: Hidrometeo vyd-vo. P. 170-177. [in Ukrainian]

3. Kovalishyna S.P., Teren"ko H.V., Hrandova M.A., Dudnyk D.S. (2010). Stan planktonnyx i bentosnyx spil"not hidrobiontiv Odes"koho pryberezhzhya Chornoho morya. Materialy XI Mizhnarodnoyi naukovopraktychnoyi ekolohichnoyi konferenciyi Vydovi populyaciyi i spil"noty $v$ pryrodnyx $i$ antropohenno-transformovanyx landshaftax: stan $i$ metody joho diahnostyky. Rosiya, Belhorod, 20-25.09.2010. [in Ukrainian]

4. Materialy do Nacional"noyi dopovidi pro stan navkolyshn"oho pryrodnoho seredovyshha v Ukrayini u 2015 r. (2016). Rukopys UkrNCEM. Odesa. [in Ukrainian]

5. Materialy do Nacional"noyi dopovidi pro stan navkolyshn"oho pryrodnoho seredovyshha v Ukrayini u 2016 r. (2017). Rukopys UkrNCEM. Odesa. [in Ukrainian]

6. Orlova I.H., Pavlenko N.E., Popov Yu.Y., Ukrayins"kyj V.V., Komorin V.N. (2002). Rezul"taty doslidzhen" hidroloho-hidroximichnoho rezhymu Odes"koho portu v ramkax mizhnarodnoho proektu «Hloballast». Tezy dop. 4-j mizhnarodnyj sympozium Ekolohichni problemy Chornoho morya. Odesa, OCNTI, 31.10.2002. P. 156-161. [in Ukrainian]

7. Zajcev Ju.P., Aleksandrova B.G., Mynychevoj G.G. (2006). Pivnichnozaxidna chastyna Chornoho morya: biolohiya, ekolohiya (The Northwest of the Black Sea: biology, ecology). Kyiv: Naukova dumka. [in Ukrainian] 